\title{
PEMBELAJARAN FISIKA PROBLEM BASED LEARNING (PBL) MENGGUNAKAN METODE EKSPERIMEN DAN METODE PROYEK DITINJAU DARI KEMAMPUAN BERPIKIR ABSTRAK SISWA
}

\author{
Indica Yona Okyranida \\ Pendidikan Fisika Universitas Indraprasta PGRI Jakarta \\ E-Mail: indicaoky@gmai.com
}

\begin{abstract}
Abstrak
Penelitian ini bertujuan untuk mengetahui pengaruh dan interaksi penggunaan model Problem Based Learning $(P B L)$, metode eksperimen, metode proyek, kemampuan berpikir abstrak terhadap hasil belajar. Desain penelitian ini adalah eksperimen. Populasi dari penelitian ini adalah siswa SMP Negeri 4 Madiun kelas VIII. Sampel diambil dengan teknik Cluster Random Sampling, sampel terdiri dari 2 kelas yaitu kelas VIII A dan VIII B. Kelas VIII A diberi pembelajaran dengan Problem Based Learning (PBL) menggunakan metode eksperimen, sedangkan VIII B diberi pembelajaran Problem Based Learning (PBL) dengan metode proyek. Data hasil belajar kognitif, kemampuan berpikir abstrak dan kemampuan berpikir kreatif diambil menggunakan instrumen tes, sedangkan data hasil belajar afektif dan psikomotor menggunakan lembar observasi. Data dianalisis menggunakan analisis variansi anava dua jalan dan dilanjutkan dengan uji Compare Means. Hasil penelitian menunjukkan: 1) tidak terdapat pengaruh pembelajaran fisika Problem Based Learning (PBL) menggunakan metode eksperimen dan proyek terhadap hasil belajar; 2) terdapat pengaruh kemampuan berpikir abstrak terhadap hasil belajar kognitif dan psikomotor, namun tidak terdapat pengaruh terhadap hasil belajar afektif; 3) tidak terdapat interaksi pembelajaran fisika Problem Based Learning (PBL) mengunakan metode eksperimen dan proyek dengan kemampuan berpikir abstrak terhadap hasil belajar.
\end{abstract}

Kata kunci: Problem Based Learning (PBL), metode eksperimen, metode proyek, kemampuan berpikir abstrak.

\section{PENDAHULUAN}

Physics Olympiad (IPhO) ke-47 tahun 2016 yang dilaksanakan di Swiss dan diikuti 87 negara dengan total 650 siswa Indonesia mencetak prestasi dengan meraih satu emas dan empat perak. Prestasi tersebut meningkat dari tahun 2015, Indonesia hanya meraih medali perak. Prestasi Indonesia ditingkat Internasional yang semakin meningkat membuktikan kesriusan pemerintah dalam memperbaiki pendidikan. Namun, meningkatnya prestasi belajar fisika ditingkat Internasional tidak diimbangi dengan prestasi Nasional. Dilihat dari hasil Ujian Nasional pada mata pelajaran fisika mengalami penurunan dari tahun lalu.

PISA (Programme for International Student Assesment) yang bertujuan meneliti secara berkala tentang kemampuan siswa untuk usia 15 tahun (kelas IX SMP dan kelas $X$
SMA) dalam membaca (reading literacy), matematika (mathematics literacy) dan IPA (scientifics literacy). Hasil tes PISA pada tahun 2003 di bidang sains, Indonesia berada pada peringkat ke-38 diantara 41 negara peserta. Sedangkan pada tes PISA tahun 2006, dari 57 negara peserta Indonesia menduduki peringkat ke-50. Dari data PISA tahun 2006 di atas, menunjukkan bahwa 61,6\% pelajar Indonesia memiliki kemampuan sains terbatas sedangkan yang mampu melakukan penelitian secara sederhana sebanyak $27,5 \%$, pelajar yang mampu mengidentifikasi masalah-masalah ilmiah hanya $9,5 \%$ dan pelajar yang mampu memanfaatkan sains dalam kehidupan seharihari tercatat sebanyak 1,45\% (Sudarisman, 2010).

TIMSS (Trend in International Mathematics and Science Study) adalah studi Internasional untuk siswa kelas IV dan VII dalam bidang matematika dan IPA yang 
dilaksanakan setiap empat tahun. TIMSS dilaksanakan untuk mengetahui tingkat pencapaian siswa diberbagai negara di dunia sekaligus memperoleh informasi yang bermanfaat tentang konteks pendidikan matematika dan IPA. Berdasarkan hasil tes TIMSS pada tahun 1999, menunjukkan bahwa diantara 38 negara peserta, hasil belajar sains siswa SMP kelas VII Indonesia berada pada urutan ke-32 dan 34 untuk matematika. Sedangkan hasil tes TIMSS pada tahun 2003, kemampuan matematika siswa SMP kelas VII Indonesia berada pada peringkat ke-34 dari 45 negara peserta. Di bidang sains Indonesia berada pada peringkat ke-36 (Hayat, 2010).

Physics Olympiad (IPhO) ke-47 tahun 2016 yang dilaksanakan di Swiss dan diikuti 87 negara dengan total 650 siswa Indonesia mencetak prestasi dengan meraih satu emas dan empat perak. Prestasi tersebut meningkat dari tahun 2015, Indonesia hanya meraih medali perak. Prestasi Indonesia ditingkat Internasional yang semakin meningkat membuktikan kesriusan pemerintah dalam memperbaiki pendidikan. Namun, meningkatnya prestasi belajar fisika ditingkat Internasional tidak diimbangi dengan prestasi Nasional. Dilihat dari hasil Ujian Nasional siswa SMA/MA pada mata pelajaran fisika mengalami penurunan dari tahun lalu.

Hal tersebut menunjukkan masih kurangnya hasil belajar Indonesia ditingkat Internasional yang merupakan hal serius yang perlu diperhatikan para tenaga pendidik khususnya bidang sains. Para tenaga pendidik harus berusaha mengikuti perubahan secara cepat yang terjadi pada dunia pendidikan. Sehingga dapat menciptakan generasi penerus bangsa yang berkompeten dan mampu bersaing ditingkat internasional.

Kegiatan belajar siswa di sekolah bertujuan membawa siswa menuju ke keadaan yang lebih baik dari segi kognitif, afektif dan psikomotornya yang bersifat permanen. Hasil dari pembelajaran yang bersifat permanen membuat guru harus benar-benar mempersiapkan pembelajaran dengan baik, agar tidak terjadi kesalahan konsep. Pembelajaran fisika merupakan materi yang baru didapat siswa pada saat SMP karena ketika duduk di bangku Sekolah Dasar (SD) siswa hanya mendapat pembelajaran IPA. Oleh karena itu, siswa sering mengalami kesulitan dalam belajar fisika. Perpaduan konsep dan teori yang saling berkaitan ditambah lagi materi bersifat abstrak dan komplek, siswa harus memiliki kreativitas yang baik.

Konsep pada pembelajaran fisika di SMP perlu ditanamkan dengan kuat agar siswa tidak mengalami kesulitan ketika berada pada jenjang yang lebih tinggi. Pembelajaran fisika lebih baik dikemas dalam pembelajaran yang menekankan pada konsep dan melatih siswa berpikir kreatif pada materi yang bersifat abstrak, sehingga siswa bisa menjadi tertarik dalam mempelajari fisika.

SMP Negeri 4 Madiun merupakan salah satu sekolah yang letaknya strategis dan merupakan sekolah favorit di Madiun. Siswa yang masuk di SMP Negeri 4 mempunyai kemampuan di bidang akademik ataupun nonakademik yang berbeda-beda. Hasil Ujian Nasional (UN) merupakan salah satu cara untuk melihat keberhasilan proses pembelajaran.

Dari data Ujian Nasional (UN) mata pelajaran IPA dibagi menjadi fisika dan biologi. Didapat bahwa materi cahaya memiliki nilai yang paling rendah ditingkat nasional yaitu 61,26 . Hal itu membuktikan bahwa mata pelajaran fisika pada materi cahaya merupakan materi yang sulit bagi siswa.

Hasil pengamatan yang dilakukan saat pembelajaran berlangsung diperoleh penyebab hasil UN fisika rendah yaitu kurang seriusnya siswa dalam mengikuti pelajaran, siswa cenderung ada yang tidak memperhatikan saat pelajaran, masa bodoh, dan kurangnya motivasi untuk belajar. Sikap siswa yang seperti itu sangat mempengaruhi ketidaktercapaian tujuan pembelajaran dan menjadikan siswa mengalami kegagalan dalam belajar.

Masalah-masalah tersebut dapat diselesaikan dengan guru harus mengetahui kemampuan masing-masing siswa. Untuk mengetahui lebih dalam masing-masing kemampuan siswa, guru dapat menggunakan tes kemampuan berpikir yang sesuai dengan pembelajaran fisika seperti kemampuan 
berpikir abstrak. Dengan mengetahui kemampuan siswa terlebih dahulu, dapat membantu ketercapaian tujuan pembelajaran dengan memberikan pembelajaran khusus bagi siswa yang memiliki kemampuan berpikir rendah.

Guru harus mempersiapkan pembelajaran dengan model atau metode yang disesuaikan dengan materi pembelajaran fisika. Model dan metode yang dipilih ditekankan dapat memberi pembelajaran yang bermakna pada siswa sehingga dapat membantu ingatan siswa dalam jangka watu yang panjang. Pembelajaran fisika yang materinya bersifat abstrak dan susah dipahami harus dikemas dengan pembelajaran yang menyenangkan. Penggunaan model Problem Based Learning ( $P B L$ ) siswa diberi stimulus permasalahan sebelum memulai pembelajaran. Permasalahan yang diberikan guru mengarahkan pemikiran kreatif siswa pada materi yang akan diajarkan. Siswa memberi asumsi-asumsi jawaban dari permasalahan tersebut dapat dibuktikan dengan suatu eksperimen ataupun proyek. Dengan menggunakan metode eksperimen dan metode proyek siswa menemukan sendiri konsep dari materi fisika yang diajarkan sehingga dapat mengalami proses eksperimen ataupun pembuatan proyek. Siswa dapat mengembangkan pemikiran mereka secara abstrak ataupun kreatif, selain itu juga dapat menjadikan pembelajaran tersebut menjadi bermakna dan diingat dalam jangka waktu yang panjang.

Guru mengajak siswa untuk melakukan percobaan, tidak harus menggunakan alat laboratorium. Guru bisa membuat sendiri alat sederhana untuk melakukan eksperimen dan proyek. Alat sederhana membantu siswa untuk menemukan konsep dari pembelajaran fisika. Oleh karena itu, pengembangan alat sederhana perlu dilakukan oleh guru untuk memperkaya pengetahuan siswa. Pembelajaran yang dikemas dengan menyenangkan oleh guru dapat membuat siswa menjadi lebih tertarik untuk belajar fisika. Saat diajak untuk eksperimen dan membuat suatu proyek, siswa akan lebih antusias dalam pembelajaran. Ketertarikan siswa saat proses pembelajaran juga akan berpengaruh pada hasil belajar siswa.

Kemampuan berpikir abstrak siswa SMP Negeri 4 Madiun sudah cukup baik. Dilihat dari data kemampuan berpikir abstrak banyak siswa yang memperoleh hasil diatas rata-rata.

Materi cahaya yang bersifat abstrak membuat siswa kesulitan untuk memahaminya. Dengan menggunakan model Problem Based Learning ( $P B L$ ) dikembangkan dengan metode ekperimen dan metode proyek ditinjau dari kemampuan berpikir abstrak siswa dapat mengalami sendiri proses pembelajaran menuju konsep yang diharapkan siswa dapat mencapai tujuan pembelajaran. Sehingga membuat siswa lebih antusias dalam pembelajaran dan dapat memperbaiki nilai pada mata pelajaran fisika khususnya materi Cahaya.

Pada penelitian yang dilakukan Macho (2012) penggunaan strategi Problem Based Learning ( $P B L)$ harus disesuaikan dengan kondisi lokal, tujuan pendidikan, dan budaya tradisi untuk mengatasi kendala SDM ditunjukkan bahwa Problem Based Learning $(P B L)$ kurang efektif dalam pembelajaran fisika jika tidak memberikan pengalamanpengalaman nyata yang merangsang aktivitas siswa untuk belajar. Pemilihan materi juga menjadi kendala yang besar untuk memadukan antara Problem Based Learning (PBL) dan metode eksperimen (Kusumawati, 2013). Belum banyak yang melakukan penelitian menggunakan Problem Based Learning (PBL) dengan metode proyek karena kurikulum yang berlaku di Indonesia belum menunjang serta memerlukan keahlian khusus dari guru, sementara guru belum disiapkan untuk hal ini (Asmani, 2011). Berdasarkan kajian teoritis dan empiris pada latar belakang maka penting dilakukan penelitian yang bertujuan untuk memperbaiki pembelajaran Problem Based Learning (PBL) menggunakan metode eksperimen dan metode proyek agar dapat digunakan dalam proses belajar mengajar di sekolah untuk mencapai tujuan pembelajaran yang diharapkan. 


\section{METODE PENELITIAN}

Populasi dalam penelitian ini adalah siswa kelas VIII SMP Negeri 4 Madiun tahun pelajaran 2014/2015 yang terdiri dari 9 kelas dengan jumlah siswa sebanyak 306. Teknik pengambilan sampel dalam penelitian ini menggunakan teknik cluster random sampling. Desain penelitian yang digunakan adalah penelitian eksperimen yang bertujuan untuk mengetahui pengaruh dan interaksi antara suatu variabel terhadap variabel lainnya. Penelitian ini bersifat eksperimental dengan rancangan data penelitian disajikan dalam desain faktorial $2 \times 2$ dengan teknik analisis varians (Anava).

Instrumen yang digunakan berupa silabus, RPP dan instrumen pengambilan data berupa tes dan lembar observasi. Instrumen bentuk tes untuk mengukur hasil belajar kognitif, kemampuan berpikir abstrak dan kemampuan berpikir kreatif. Instrumen bentuk tes menggunakan tes pilihan ganda untuk soal kognitif dan tes esai untuk tes kemampuan berpikir abstrak dan kemampuan berpikir kreatif. Lembar observasi digunakan untuk mengukur hasil belajar afektif dan psikomotorik pada saat penelitian.

Uji validasi instrumen dilakukan oleh ahli sebelum diujicobakan. Setelah uji coba instrumen hasil belajar kognitif, kemampuan berpikir abstrak dan keterampilan berpikir kreatif diuji validitas, reliabilitas, taraf kesukaran dan uji daya pembeda soal.

\section{HASIL DAN PEMBAHASAN}

Uji hipotesis menggunakan uji Anava. Untuk menganalisis data dilakukan dengan SPSS 18. Hasil hipotesis dirangkum dalam tabel 1.

\begin{tabular}{lllll}
\hline No. & $\begin{array}{l}\text { Hipotesis } \\
\text { dengan } \\
\text { ANAVA }\end{array}$ & $\begin{array}{l}\text { Sig. } \\
\text { Kogni- } \\
\text { tif }\end{array}$ & $\begin{array}{l}\text { Sig. } \\
\text { Afektif }\end{array}$ & $\begin{array}{l}\text { Sig. } \\
\text { Psiko- } \\
\text { motor }\end{array}$ \\
\hline 1. & Hipotesis 1 & 0,192 & 0,322 & 0,314 \\
2. & Hipotesis 2 & 0,000 & 0,300 & 0,014 \\
3. & Hipotesis 3 & 0,612 & 0,330 & 0,311 \\
\hline
\end{tabular}

Dari hasil analisis anava, jika sig. $>0,05$; maka Ho diterima sedangkan jika sig. < 0,05; maka Ho ditolak. Dari Tabel 1 dapat dibahas hipotesis untuk data hasil belajar kognitif, afektif dan psikomotor sebagai berikut:

a. Hipotesis pertama, mengenai pengaruh metode pembelajaran terhadap hasil belajar kognitif, afektif dan psikomotor.

Hasil hipotesis pengaruh metode pembelajaran pada hasil belajar kognitif diperoleh signifikan 0,192 , hasil belajar afektif diperoleh signifikan sebesar 0,322 dan hasil belajar psikomotor diperoleh signifikan sebesar 0,314 . Berdasarkan hasil keputusan uji maka $\mathrm{H}_{0}$ diterima pada hasil belajar kognitif, afektif, dan psikomotor. Hal ini dapat disimpulkan bahwa tidak ada pengaruh pembelajaran Problem Based Learning (PBL) menggunakan metode eksperimen dan proyek terhadap hasil belajar kognitif, afektif, dan psikomotor. Sehingga hal ini tidak sesuai dengan hipotesis awal yang menyatakan bahwa terdapat pengaruh pembelajaran Problem Based Learning (PBL) menggunakan metode eksperimen dan proyek terhadap hasil belajar kognitif, afektif, dan psikomotor.

Data menunjukkan bahwa rata-rata hasil belajar kognitif pada kelompok yang menggunakan metode eksperimen adalah 75,41 dan pada kelompok menggunakan metode proyek adalah 77,03. Hasil belajar afektif pada kelompok yang menggunakan metode eksperimen adalah 70,64 dan pada kelompok menggunakan metode proyek adalah 73,26 . Hasil belajar psikomotor pada kelompok yang menggunakan metode eksperimen adalah 77,61 dan pada kelompok menggunakan metode proyek adalah 79,12. Dari rata-rata di atas diperoleh bahwa tidak ada perbedaan yang signifikan hasil belajar siswa antara metode eksperimen dan metode proyek. Hal tersebut dipengaruhi oleh beberapa faktor yaitu pertama, kedua metode pembelajaran memberikan konstribusi yang baik terhadap pembelajaran fisika terbukti dengan perolehan rata-rata hasil belajar siswa meningkat dari kemampuan awal siswa (kelompok eksperimen 65 dan kelompok proyek 68). Siswa juga terlibat aktif dalam pembelajaran dapat mengembangkan kemampuan dalam 
mengamati, bereksperimen, memberikan penyelesaian, dan menghubungkan antara teori dan kenyataan. Siswa pun dapat melakukan pengujian kesimpulan atau pembuktian kembali konsep yang sudah ditemukan saat melakukan eksperimen sehingga dengan metode ini dapat membuat pembelajaran semakin jelas dan pengetahuan yang didapat siswa menjadi lebih kongkret. Berdasarkan analisis pada dasarnya kedua metode ini memberikan pengaruh positif kepada pembentukan sikap siswa dikarenakan banyaknya terjadi interaksi dengan teman sehingga dapat menumbuhkan nilai kepedulian antar teman sekelompok ataupun berbeda kelompok.

Kedua, materi yang digunakan pada penelitian ini adalah cahaya. Materi ini sangat dekat sekali dengan kehidupan sehari-hari sehingga siswa lebih mudah untuk mempelajarai dan mengasumsikan pendapat mereka tentang hal-hal yang berhubungan dengan cahaya. Siswa membutuhkan pemikiran yang imajinatif untuk menyusun sebuah asumsi yang terjadi tentang akibat dan keuntungan adanya cahaya.

Ketiga, respon siswa yang diberikan terhadap kedua metode pembelajaran yang diterapkan adalah sama baik. Siswa pada kelompok eksperimen antusias dalam melakukan percobaan. Kelompok proyek juga tanggap terhadap permasalahan yang diberikan guru untuk merancang dan menyusun sebuah proyek. Respon siswa juga berpengaruh besar terhadap hasil belajar yang akan diperoleh siswa setelah pembelajaran. Semakin baik respon siswa terhadap pembelajaran semakin baik pula hasil belajarnya, sebaliknya apabila respon siswa rendah maka akan rendah juga hasil belajar siswa.

Hasil penelitian ini sesuai dengan teori yang dinyatakan Ausubel bahwa pembelajaran yang baik adalah belajar yang bermakna, pada Problem Based Learning (PBL) memberikan kontribusi pembelajaran bermakna yang cocok digunakan pada mata pelajaran sains. Pada penelitian yang dilakukan Selcuk, Caliskan, dan Mahmed (2013) menyimpulkan bahwa Problem
Based Learning (PBL) tidak memberikan pengaruh yang signifikan secara statistik tetapi memberikan pengaruh yang baik pada hasil belajar fisika dan menumbuhkan keberhasilan siswa dalam pencapaian belajar dan siswa menjadi aktif untuk melakukan proses belajarnya sendiri.

b. Hipotesis kedua mengenai pengaruh kemampuan berpikir abstrak terhadap hasil belajar kognitif, afektif, dan psikomotor.

Hasil hipotesis pengaruh kemampuan berpikir abstrak pada hasil belajar kognitif diperoleh signifikan 0,000, hasil belajar afektif diperoleh signifikan sebesar 0,300 dan hasil belajar psikomotor diperoleh signifikan sebesar 0,014 . Berdasarkan hasil keputusan uji maka $\mathrm{H}_{0}$ ditolak pada hasil belajar kognitif dan psikomotor sedangkan pada hasil belajar afektif $\mathrm{H}_{0}$ diterima. Hal ini dapat disimpulkan bahwa ada pengaruh kemampuan berpikir abstrak terhadap hasil belajar kognitif dan psikomotor. Hal ini sesuai dengan hipotesis awal yang menyatakan bahwa ada pengaruh kemampuan berpikir abstrak terhadap hasil belajar kognitif dan psikomotor. Tidak ada pengaruh kemampuan berpikir abstrak terhadap hasil belajar afektif. Sehingga hal ini tidak sesuai dengan hipotesis awal yang menyatakan bahwa ada pengaruh kemampuan berpikir abstrak terhadap hasil belajar afektif.

Berdasarkan uji lanjut compare means diperoleh rata-rata hasil belajar kognitif siswa yang memiliki kemampuan berpikir abstrak tinggi adalah 79,24 dan siswa yang memiliki kemampuan berpikir abstrak rendah adalah 72,24 . Hal ini menunjukkan siswa yang memiliki kemampuan berpikir abstrak tinggi hasil belajar kognitifnya lebih baik dari pada siswa yang memiliki kemampuan berpikir abstrak rendah. Hasil belajar psikomotor, siswa yang memiliki kemampuan berpikir abstrak tinggi adalah 78,86 dan siswa yang memiliki kemampuan berpikir abstrak rendah adalah 78,00. Hal ini menunjukkan bahwa rata-rata nilai hasil belajar psikomotor pada kemampuan berpikir abstrak tinggi dan rendah memberikan pengaruh yang signifikan. 
Kemampuan berpikir abstrak merupakan salah satu aspek internal yang berpengaruh terhadap hasil belajar belajar. Pengaruh signifikan yang diberikan antara kemampuan berpikir abstrak terhadap hasil belajar kognitif dan psikomotor membuktikan bahwa siswa yang memiliki kemampuan berpikir abstrak tinggi memiliki kemampuan analisis abstraksi yang baik dibandingkan dengan siswa yang memiliki kempuan berpikir asbtrak rendah. Kemampuan berpikir abstrak siswa dapat mempengaruhi daya analisis yang baik untuk menciptakan ataupun menyelesaikan suatu permasalahan.

Materi cahaya dalam fisika meskipun dekat dengan kehidupan sehari-hari, tetapi perlu pemahaman karena bersifat abstrak. Cahaya merupakan perwujudan dari gelombang yang bersifat mikroskopis. Siswa perlu berimajinasi dalam menentukan pemikiran inisiatif untuk mengumpulkan dan mengolah data dari sumber yang direkomendasikan sehingga rasa keingintahuan akan terpenuhi. Ketika dihadapkan dalam perhitungan pada cahaya siswa harus menghubungkan konsep dan hasil pengamatan pada eksperimen serta proyek yang telah mereka buat. Penyelesaian yang digunakan dapat mempermudah siswa untuk mencapai tujuan pembelajaran yang diharapkan.

Ranah afektif mencangkup segala sesuatu yang berhubungan dengan emosi. Hasil hipotesis menunjukkan bahwa tidak ada pengaruh kemampuan berpikir abstrak terhadap hasil belajar afektif. Hal ini dikarenakan beberapa faktor, seperti motivasi siswa saat pembelajaran berlangsung sangat antusias baik siswa yang memiliki kemampuan berpikir abstrak tinggi ataupun rendah. Siswa memiliki kedisiplinan yang baik ketika pembelajaran tidak ada yang datang terlambat, sehingga waktu tidak terbuang. Kedisiplinan sangat perlu ditingkatkan karena dengan disiplin siswa dapat memperbaiki kemampuan mereka baik berupa hasil belajar ataupun kehidupan keseharian. Pada saat praktikum berlangsung siswa bekerja sama dan saling membantu dalam kelompok. Siswa saling bertukar informasi antar kelompok pada forum pengayakan. Semua siswa berusaha untuk membangun pemahaman mereka masingmasing sehingga diharapkan siswa mampu meningkatkan hasil belajar. Hal ini dapat disimpulkan siswa memiliki hasil belajar afektif yang baik sehingga tidak memberikan pengaruh yang signifikan pada kemampuan berpikir abstrak tinggi ataupun rendah.

$\mathrm{Hal}$ ini sesuai dengan penelitian Yuniyanti (2012) yang menyebutkan bahwa kemampuan berpikir abstrak berpengaruh terhadap hasil belajar siswa. Dalam penelitian ini dapat disimpulkan bahwa siswa yang memiliki kemampuan berpikir abstrak tinggi memiliki hasil belajar kognitif dan psikomotor lebih baik daripada siswa yang memiliki kemampuan berpikir abstrak rendah.

c. Hipotesis ketiga mengenai interaksi pembelajaran Problem Based Learning $(P B L)$ menggunakan metode eksperimen dan metode proyek dengan kemampuan berpikir abstrak terhadap hasil belajar kognitif, afektif, dan psikomotor.

Hasil hipotesis interaksi pembelajaran berbasis Problem Based Learning (PBL) menggunakan metode eksperimen dan metode proyek dengan kemampuan berpikir abstrak terhadap hasil belajar kognitif menunjukkan signifikan sebesar 0,615 , hasil belajar afektif sebesar 0,330 dan hasil belajar psikomotor sebesar 0,331. Berdasarkan hasil keputusan uji maka $\mathrm{H}_{0}$ diterima pada hasil belajar kognitif, afektif dan psikomotor. Hal ini dapat disimpulkan bahwa tidak terdapat interaksi pembelajaran Problem Based Learning (PBL) menggunakan metode eksperimen dan proyek terhadap hasil belajar afektif, kognitif, dan psikomotor. Sehingga hal ini tidak sesuai dengan hasil hipotesis awal yang menyatakan bahwa terdapat interaksi pembelajaran berbasis Problem Based Learning(PBL) terhadap hasil belajar kognitif, afektif, dan psikomotor. Hal itu dipengaruhi beberapa faktor.

Hasil belajar kognitif untuk siswa yang memiliki kemampuan berpikir abstrak tinggi sebesar 78,66 dan siswa yang memiliki kemampuan berpikir abstrak rendah 72,35. Hasil belajar afektif siswa yang memiliki kemampuan berpikir abstrak tinggi 72,73 dan 
siswa yang memiliki kemampuan berpikir abstrak rendah memiliki hasil belajar afektif sebesar 70,76. Hasil belajar psikomotor siswa yang memiliki kemampuan berpikir abstrak tinggi adalah 81,53 sedangkan siswa yang memiliki kemampuan berpikir abstrak rendah hasil belajar psikomotornya 73,38. Hasil tersebut menunjukkan bahwa siswa yang memiliki kemampuan berpikir asbtrak tinggi memiliki hasil belajar tinggi sedangkan siswa yang memiliki kemampuan berpikir abstrak rendah memiliki hasil belajar rendah. Jadi, disimpulkan bahwa siswa yang memiliki kemampuan berpikir abstrak tinggi akan tetap memiliki hasil belajar tinggi dengan menggunakan metode pembelajaran eksperimen ataupun proyek, maka tidak terdapat interaksi antara metode dengan kemampuan berpikir abstrak tinggi ataupun rendah.

Pertama, pada hasil belajar kognitif antara metode pembelajaran dan kemampuan berpikir abstrak merupakan hal yang berdiri sendiri dan tidak berkaitan. Siswa yang memiliki kemampuan berpikir abstrak tinggi ataupun rendah tidak memberikan interaksi terhadap metode pembelajaran. Siswa yang memiliki kemapuan berpikir abstrak tinggi jika diberi perlakuan dengan metode apapun akan memiliki hasil belajar yang baik begitu sebaliknya.

Kedua, pada hasil belajar afektif interaksi antara metode pembelajaran dan kemampuan berfikir abstrak tidak memberikan pengaruh yang signifikan. Karena siswa yang memiliki kemampuan berpikir abstrak tinggi dan rendah mengikuti pembelajaran dengan baik, siswa sama-sama antusias, semangat dan minat.

Ketiga, pada hasil belajar psikomotor siswa memiliki reaksi natural dalam mengikuti kegiatan pembelajaran untuk menyiapkan presentasi, menyiapkan alat bahan dalam praktikum, dan menentukan proyek yang akan dibuat siswa. Siswa yang memiliki kemampuan berpikir abstrak tinggi dan rendah sama-sama memberikan respon yang baik. Jadi, dapat disimpulkan bahwa tidak terdapat interaksi antara metode pembelajaran dengan kemampuan berpikir abstrak terhadap hasil belajar belajar kognitif, afektif, dan psikomotor. Siswa yang memiliki kemampuan berpikir abstrak tinggi dan rendah akan sama-sama dapat mengikuti pembelajaran dengan baik.

Pada teori belajar Bruner pembelajaran yang baik adalah pembelajaran penemuan dan pada penelitian ini dengan pembelajaran fisika Problem Based Learning (PBL) menggunakan metode eksperimen dan metode proyek berhubungan erat dengan kemampuan berpikir abstrak karena dengan pemikiran abstraksi, siswa dapat memecahkan suatu fenomena dengan eksperimen ataupun membuat proyek sehingga dapat dihubungkan dengan konsep pembelajaran. Sesuai dengan pernyataan Eggen (2012) yang menyatakan bahwa pemikiran teoritis adalah pengembangan dari ide abstrak dari dunia baru ini dan kemampuan yang tumbuh untuk berpikir dengan abstraksiabstraksi ini dan kemudian menghubungkan hasil-hasil pemikiran dengan dunia konkret.

\section{PENUTUP}

Hasil penelitian ini dapat disimpulkan: 1) tidak terdapat pengaruh pembelajaran Problem Based Learning menggunakan metode eksperimen dan proyek terhadap hasil belajar siswa. Pembelajaran Problem Based Learning menggunakan metode eksperimen dan metode proyek memberikan pengaruh yang sama baik terhadap hasil belajar siswa; 2) terdapat pengaruh kemampuan berpikir abstrak terhadap hasil belajar kognitif dan psikomotor. Tidak terdapat pengaruh kemapuan berpikir abstrak terhadap hasil belajar afektif. Kemampuan berpikir abstrak memberikan pengaruh terhadap hasil belajar kognitif dan psikomotor siswa tetapi tidak mempengaruhi hasil belajar afektif;3) tidak terdapat interaksi metode pembelajaran terhadap kemampuan berpikir abstrak signifikan kognitif, afektif, dan psikomotor. Metode pembelajaran dan kemampuan berpikir abstrak merupakan hal yang berbeda. Sehingga siswa yang memiliki kemampuan berpikir abstrak tinggi memiliki hasil belajar tinggi sedangkan siswa yang memiliki kemampuan berpikir abstrak rendah memiliki hasil belajar rendah. Jadi, dapat 
disimpulkan bahwa kemampuan berpikir abstrak tidak berpengaruh terhadap hasil belajar siswa

Dalam rangka turut menyumbangkan pemikiran yang berkenaan dengan peningkatan hasil belajar fisika disarankan kepada tenaga pendidik perlu mempersiapkan secara matang perangkat pembelajaran yang sesuai dengan pembelajaran. Kepada siswa dapat meningkatkan kemampuan berpikir abstrak dan kemampuan berpikir kreatif sehingga dapat mempermudah memahami materi pelajaran, membentuk kerjasama yang baik, dan saling membantu antar anggota kelompok dalam memecahkan suatu masalah.

\section{DAFTAR PUSTAKA}

Asmani, Jamal Ma'mur. (2011). 7 Tips Aplikasi PAKEM (Pembelajaran Aktif, Kreatif, Efektif, dan Menyenangkan). Jogjakarta: Diva Press.

Eggen, P. \& Kauchak, D. (2012). Strategi dan Model Pembelajaran Mengajarkan Konten dan Keterampilan Berpikir Edisi Keenam. Terjemahan oleh Satrio Wahono. 2012. Jakarta: PT. Indeks.

Hayat, B. (2010). Mutu Pendidikan. Jakarta: Bumi Aksara.

Kusumawati, D. (2013). Pembelajaran Fisika Berbasis Masalah Melalui Metode Eksperimen dan Demonstrasi Diskusi Ditijau dari Interaksi Sosial dan Sikap IImiah Siswa. Tesis Magister Pendidikan Sains UNS. Surakarta.

Selcuk, Caliskan \& Mahmed. (2013). A Comparison Of Achievement In ProblemBased, Strategic And Traditional Learning Classes In Physics. International Journal on New Trends in Education and Their Implications. Volume: 4 Issue: 1 Article: 14 ISSN 1309-6249. 154-164.

Sudarisman, S. (2010). Membangun Karakter Peserta Didik melalui Pembelajaran Biologi Berbasis Ketrampilan Proses. Pendidikan Fisika F. MIPA UNS. Proceeding Seminar Nasional VII Pendidikan Biologi FKIP UNS. ISBN 978979-1533-85-0.
Yuniyanti, Indah Dwi. (2012). Pembelajaran Kimia Menggunakan Inkuiri Terbimbing dengan Media Modul dan E - Learning Ditinjau dari Kemampuan Pemahaman Membaca dan Kemampuan Berpikir Abstrak. Tesis Magister Pendidikan Sains UNS. Surakarta. 